\title{
ANALISIS FAKTOR PERSEPSI AKADEMISI TERHADAP PENGGUNAAN BUSANA ADAT DI LINGKUNGAN SEKOLAH
}

\author{
Luh Putu Ida Harini ${ }^{1 \S}$, Kartika Sari² ${ }^{2}$ Made Susilaw ati ${ }^{3}$ \\ ${ }^{1}$ ProgramStudi Matematika, FMIPA Universitas Udayana [Email: $\underline{\text { ballidah@ @unud.ac.id] }}$ \\ ${ }^{2}$ ProgramStudi Matematika, FMIPA Universitas Udayana [Email: sarikaartika@ unud.ac.id] \\ ${ }^{3}$ ProgramStudi Matematika, FMIPA Universitas Udayana [Email: mades usilawati@ unud.ac.id] \\ ${ }^{\S}$ Corresponding Author
}

\begin{abstract}
Traditional Balinese clothing is a typical Balinese clothing that is characterized by Balinese customs used as a form of cultural protection that reflects the nature of politeness, shade, peace, and pride for the wearer. The Governor of Bali in the Regulation of the Governor of Bali Number 79 of 2018, concerning the Day for the Use of Balinese Traditional Clothing states that one of the objectives of using Balinese traditional clothing is to maintain and maintain the preservation of Balinese Traditional Clothing in order to strengthen identity, character and character, to recognize the values the aesthetic, ethical, moral, and spiritual values contained in Balinese culture and encourage increased use of local Balinese fashion products and industries. The purpose of this study was to determine the factors that influence academic perceptions of the use of traditional clothing in the school environment. This research was conducted in high schools in Denpasar, using the factor analysis method. The sample in this study were 181 respondents. The sampling technique used was purposive sampling. The results showed that the factors that influenced students' perceptions of the use of traditional clothing in the school environment were comfort in traditional clothing, knowledge of the rules of traditional dress, knowledge of traditional clothing, ethics of Balinese traditional dress and tourists and Balinese traditional clothing. These five factors can explain the diversity of students 'perceptions of 58.742 percent, with the dominant factor affecting students' perceptions of the use of traditional clothing in the school environment is comfort in traditional dress.
\end{abstract}

Keywords: factor analysis, Balinese traditional dress, perception

\section{PENDAHULUAN}

Program aturan berbusana adat Bali bagi semua pegawai pemerintahan, dan civitas akademik di lingkungan Provinsi Bali sudah diberlakukan berdasarkan Peraturan Gubernur Bali Nomor 79 Tahun 2018, tentang Hari Penggunaan Busana Adat Bali. Salah satu tujuan penggunaan busana adat Bali yang tercantum pada pergub tersebut adalah "untuk menjagadan memelihara kelestarian Busana Adat Balidalam rangka meneguhkan jati diri, karakter, danbudi pekerti, mengenali nilai-nilai estetika, etika, moral, dan spiritual yang terkandung dalam budaya Bali dan mendorong peningkatan pemanfaatan produk dan industri busana lokal Bali".

Pada awalnya Pergub No 79 Tahun 2018 ini mendapat banyak respon positif di masyarakat.
Selain untuk meningkatkan wawasan budaya daerah, berpakaian adat Bali dapat menarik perhatian wisatawan akan budaya Bali itu sendiri. Akan tetapi pada pelaksanaannya banyak muncul masalah dari pengguna busana adat Bali, terutama para siswa yang wajib menggunakan busana tersebut selama kegiatan sekolah. Selain itu busana adat Bali yang dikenakan tidak bersifat seragam sehingga banyak model dan jenis pakaian adat yang digunakan agak menyimpang dari yang seharusnya. Hal ini ternyata memunculkan banyak penilaian dan persepsi dikalangan siswa dan guru.

Bedasarkan uraian tersebut maka diangkat tujuan dari penelitian ini adalah untuk mengetahui tentang persepsi akademisi terhadap 
penggunaan busana adat di lingkungan sekolah. Penelitian ini penting dilakukan karena dengan diketahuinya gambaran umum tentang persepsi siswa dalam penggunaan busana adat Bali maka akan dapat menjadi acuan bagi pemerintah dalam rangka perbaikan kebijakan untuk meningkatkan kenyamanan siswa dalam melaksanakan peraturan yang telah ditetapkan. Sejauh ini, riset yang mengkaji tentang persepsi penggunaan pakaian adat Bali di lingkungan sekolah sebagai tindak lanjut pelaksanaan peraturan gubernur Bali belum pernah dilakukan.

Persepsi merupakan proses untuk mengetahui atau mengenali suatu objek atau kejadian objektif dengan menggunakan sarana panca indera, kesadaran dari dan kesadaran intuitif mengenai suatu kebenaran atau keyakinan terhadap sesuatu (Caplin, 2008). Faktor yang memengaruhi suatu persepsi diantaranya adalah suasana hati, faktor situasi dan pengalaman, sistem syaraf individu, motivasi serta kepribadian. Adapun jenis persepsi dibedakan menjadi dua yaitu 1) persepsi yang berorientasi pada lingkungan fisik atau suatu proses persepsi dengan benda sebagai objek, dan 2) persepsi terhadap manusia atau disebut interpersonal yaitu proses presepsi dengan manusia sebagai objeknya.

Selama ini peraturan tentang penggunaan busana adat Bali lebih sering mengacu pada aturan penggunaanya pada saat berlangsungnya suatu upacara keagamaan. Aturan berbusana adat di Bali dikenal dengan konsep Tri Angga, yang terdiri dari:

1. Pakaian Uttama Angga yaitu pakaian yang dipakai dibagian kepala.

2. Pakaian Madyama Angga yaitu pakaian pada bagian badan,

3. Pakaian Kanistama Angga yaitu pakaian dari bagian pinggang ke bawah.

Pada peraturan Gubernur Bali, unsur busana adat Bali untuk wanita minimal terdiri atas: a. kebaya (untuk madyama angga); b. kamen dan selendang (senteng) untuk kanistama angga; dan c. tata rambut rapi untuk uttama angga. Sedangkan busana Adat Bali untuk pria minimal terdiri atas: a. destar (udeng) untuk utamma angga; b. baju untuk madyama angga; $c$. kampuh, selendang dan kamen untuk kanistama angga.

Mantra (1996) mengemukakan bahwa globalisasi membuka kesempatan yang luas untuk berbagai hal dan membawa perubahan mendasar dan kemajuan besar dalam kehidupan bermasyarakat termasuk perubahan trend dalam model dan tatanan berbusana adat Bali. Beberapa penyebab dari perubahan trend tersebut diantaranya:

1. Banyaknya fashion yang dikembangkan menggunakan bahan dan melibatkan unsur budaya Bali yang kemudian dipakai oleh selebritis dan para model, sehingga banyak ditiru oleh masyarakat.

2. Munculnya trend baru dalam berbusana akibat kombinasi model busana non lokal dan model busana lokal.

3. Banyaknya wisatawan yang menyukai adat budaya Bali termasuk busana sehingga banyak yang mengembangkan busana adat Bali sebagai barang dagangan.

4. Perkembangan trend busana modern yang merubah keberadaan dan model busana adat Bali.

5. keberadaan anak muda yang dengan mudah mengadopsi trend terbaru seperti kamen jadi, kebaya nasional dan yang lainnya.

Akibat globalisasi tersebut juga diiringi dengan muncul dampak terutama perubahan trend berbusana diantaranya :

1. Asal mengikuti trend dan kurang tanggap dan sadar terhadap filosofi yang terkandung dari simbul pakaian adat.

2. Memudarnya etika berbusana, seperti penggunaan kebaya yang bahan kainnya tarnsfaran dan pemakaian kamen yang dimodifikasi atau pemakaiannya terlalu tinggi (diatas lutut).

3. Kemungkinan munculnya pikiran-pikiran kotor dipura akibat pemakaian busana yang tranfaran dan terlalu vulgar sehingga mengganggu kenyamanan saat sembahyang.

4. Berkembangnya terus model pakaian terbaru, sehingga dapat menimbulkan kesenjangan dan adanya persaingan dalam mengikuti mode berbusana.

\section{METODE PENELITIAN}

Data yang digunakan pada penelitian ini merupakan data primer yang diperoleh dengan metode survei melalui penyebaran kuesioner. Data yang diperoleh berupa data persepsi responden tentang faktor-faktor yang memengaruhi persepsi akademisi dalam menggunakan busana adat Bali di lingkungan sekolah. Populasi yang dilibatkan pada penelitian ini adalah murid/siswa SMA/SMK yang berada dilingkungan Kota Denpasar yang 
menggunakan busana adat Bali sesuai Peraturan Gubernur Bali. Adapun sampel yang diambil pada penelitian ini adalah sebanyak 200 responden dengan menggunakan purposive sampling sebagai metode teknik pengambilan sampel yang merupakan metode pengambilan sampel sesuai dengan persyaratan sampel yang diperlukan dan dianggap cocok sebagai sumber data (Sugiono,2001). Dalam penelitian ini persyaratan sampel yang dimaksud adalah siswa yang bersedia memberikan tanggapan terhadap kuisioner ini, yang terkait dengan persepsi akademisi dalam menggunakan busana adat Bali di lingkungan sekolah.

Variabel-variabel yang digunakan pada penelitian ini

1. Pengetahuan tentang aturan berbusana adat dengan indikator sosialisasi aturan, tujuan dan arahan yang ingin disasar

2. Pengetahuan tentang Busana dan etika berbusana adat meliputi indikator berikut:

a. Pengetahuna busana adat meliputi : pengertian busana adat, fungsi, pengelompokan dan busana adat di berbagai kesempatan

b. Etika berbusana adat meliputi pengertian etika berbusana adat, keserasia berbusana adat, penerapan etika berbusana adat dan etika berbusana adat di lingkungan sekolah.

3. Kenyamanan dalam berbusana adat meliputi indikator suhu, keluwesan bergerak, konsentrasi daam belajar, dan rasa percaya diri dalam berbusana adat.

Variabel-variabel pada penelitian ini terangkum dalam 17 pertanyaan dengan jawaban responden diukur pada skala interval 010. Dalam pelaksanaannya responden pada saat mengisi kuesioner diwajibkan memilih jawaban yang paling tepat dari interval 0 sampai 10 . Sebelum disebar ke responden, kwesioner yang merupakan instrumen penelitian, akan diuji terlebih dahulu untuk memastikan kuisioner yang digunakan sudah valid dan reliabel. Adapun metode yang biasanya digunakan untuk memvalidasi kuisioner adalah metode korelasi product-momen yang disajikan dengan rumus berikut:

$$
r_{x y}=\frac{N \sum X Y-\left(\sum X\right)\left(\sum Y\right)}{\sqrt{N \sum X^{2}-\left(\sum X\right)^{2}} \sqrt{N \sum Y^{2}-\left(\sum Y\right)^{2}}}
$$

Dengan $X=$ Skorbutir tes, $Y=$ Skor total keseluruhan item dan $N=$ Jumlah responden. Selanjutnya dihitung dengan uji- $t$ menggunakan rumus:

$$
t_{\text {hitung }}=\frac{r \sqrt{n-2}}{\sqrt{1-r^{2}}}
$$

dengan $t$ menyatakan nilai $t_{\text {hitung }}, n$ merupakan jumlah responden dan $r$ merupakan koefisien korelasi hasil $r_{x y}$. Nilai $t_{\text {hitung }}$ selanjutnya dibandingkan dengan nilai $t_{\text {tabel }}$, apabila $t_{\text {hitung }}>t_{\text {tabel }}$ maka peubah dianggap valid. Selanjutnya akan dilakukan uji reliabilitas (reliability test) untuk mengetahui besarnya tingkat reliabilitas yang digunakan untuk mengkaji seberapa besar kemampuan suatu pengukur mengukur dengan stabil dan konsisten. Hal ini dapat ditunjukkan oleh nilai koefisiennya yang selanjutnya disebut sebagai koefisien reliabilitas. Pada penelitian ini, nilai reabilitas dihitung menggunakan metode Cronbach's coefficient alpha yang bertujuan untuk menghitung rata-rata interkorelasi antara butir-butir pertanyaan yang terdapat dalam kuesioner. Suatu peubah dikatakan reliable apabila nilai $\alpha>0,5$. Adapun rumus untuk menghitung Cronbach's coefficient alpha sebagai berikut :

$$
\alpha=\frac{k}{k-1}\left(1-\frac{\sum \sigma_{x_{i}}^{2}}{\sigma_{x}^{2}}\right)
$$

Dengan $\alpha$ adalah Cronbach's coefficient alpha, $k$ adalah banyaknya pertanyaan pada kuesioner, sedangkan $\sum \sigma_{x_{i}}^{2}$ merupakan jumlahan varian skor pada tiap pertanyaan dan $\sigma_{x}^{2}$ adalah varian dari total skor.

Data pada penelitian ini akan diolah dengan menggunakan program SPSS versi 20.0 For Window. Sedangkan untuk mencapai tujuan penelitian digunakan analisis faktor dengan langkah analisis sebagai berikut:

1. Melakukan uji validitas dan dilanjutkan dengan uji reliabilitas untuk mengetahui apakah kuisioner yang telah dirancang terbukti valid dan reliabel.

2. Melakukan pengujian terhadap variabelvariabel dengan metode Bartlett Test of Sphericity, metode Kaiser-Meyer Olkin (KMO), dan measure of sampling adequacy (MSA).

3. Melakukan analisis faktor dengan tahapan berikut:

a. menurunkan satu atau lebih faktor dari variabel yang sudah lolos uji pada uji variabel sebelumnya.

b. melakukan proses faktor rotasi terhadap faktor yang telah terbentuk yang bertujuan untuk mempertegas variabel 
yang masuk ke dalam faktor tertentu. Berdasar proses rotasinya, metode rotasi dibedakan menjadi dua yaitu rotasi ortogonal (orthogonal rotation) dan oblique rotation. Rotasi orthogonal menghasilkan faktor yang tidak memiliki korelasi satu dengan yang lain sedangkan sebaliknya oblique rotation dipergunakan apabila faktor pada populasi diketahui berkorelasi sangat kuat.

4. Melakukan interpretasi atas faktor yang telah diperoleh dengan memberi nama atas faktor yang dipercaya dapat mewakili variabel-variabel faktor tersebut.

\section{HASIL DAN PEMBAHASAN}

\section{a. Uji Validitas dan Uji Reliabilitas Kuesoiner}

Langkah awal dari penelitian ini adalah melakukan uji validitas dan uji reliabilitas kuesoiner. Pengujian validitas dan reliabilitas kuesioner penelitian dilakukan terlebih dahulu dari data hasil penyebaran kuesioner kepada 30 sisw a SMA/SMK di Kota Denpasar. Semua item pertanyaan dalam penelitian adalah valid, sehingga item pertanyaan dapat digunakan untuk pengukuran selanjutnya.

Hasil analisis reliabilitas kuesioner pada penelitian ini memperlihatkan bahwa nilai Alpha Cronbach's pada semua item pertanyaan lebih besar dari 0,5, sehingga dapat disimpulkan bahwa kuesioner yang telah disusun dan akan digunakan untuk penelitian ini bersifat reliabel.

\section{b. Gambaran Umum Data}

Sebanyak 200 kuisioner disebarkan kepada siswa-siswa SMA/SMK di Kota Denpasar. Dari 200 kuisioner tersebut ada 181 kuisioner yang dapat digunakan untuk analisis selanjutnya, karena sudah dijawab secara lengkap oleh responden. Karakteristik siswa yang dilihat adalah Jenis Kelamin, Asal Sekolah, dan Agama. Berdasarkan jenis kelamin ada lebih banyak responden pria pada penelitian ini, yaitu 107 adalah pria, dan 74 adalah wanita, sedangkan karakteristik Asal Sekolah Siswa dapat dilihat pada Tabel 1.

Penyebaran kuisioner dalam penelitian ini tidaklah proposional, sebagian besar responden berasal dari SMA Negeri. Penyebaran kuisioner yang dilakukan pada akhir masa sekolah yaitu dari akhir Juni 2019 sampai masa liburan yaitu akhir Juli 2019 merupakan salah satu alasan tidak meratanya responden berdasarkan asal sekolah. Karakteristik siswa berdasarkan agamanya, bahwa sebagian besar (141 siswa) yang menjadi responden beragama Hindu, hal ini wajar karena mayoritas penduduk di Kota Denpasar beragama Hindu.

Tabel 1. Karakteristik Asal Sekolah Siswa

\begin{tabular}{|l|c|l|c|}
\hline Asal Sekolah & Jumlah & $\begin{array}{l}\text { Asal } \\
\text { Sekolah }\end{array}$ & Jumlah \\
\hline SLUA Denpasar & 18 & $\begin{array}{l}\text { SMAN 5 } \\
\text { Denpasar }\end{array}$ & 2 \\
\hline SMA Dwijendra & 6 & $\begin{array}{l}\text { SMAN 6 } \\
\text { Denpasar }\end{array}$ & 1 \\
\hline SMA Harapan & 3 & $\begin{array}{l}\text { SMAN 7 } \\
\text { Denpasar }\end{array}$ & 30 \\
\hline $\begin{array}{l}\text { SMA } \\
\text { Muhammadiy ah }\end{array}$ & 2 & $\begin{array}{l}\text { SMAN 8 } \\
\text { Denpasar }\end{array}$ & 3 \\
\hline $\begin{array}{l}\text { SMA PGRI 2 } \\
\text { Denpasar }\end{array}$ & 14 & $\begin{array}{l}\text { SMK 4 } \\
\text { Denpasar }\end{array}$ & 3 \\
\hline $\begin{array}{l}\text { SMA PGRI 4 } \\
\text { Denpasar }\end{array}$ & 1 & $\begin{array}{l}\text { SMK } \\
\text { Pariwisata } \\
\text { Kertay asa }\end{array}$ & 4 \\
\hline $\begin{array}{l}\text { SMAK Santo } \\
\text { Yoseph }\end{array}$ & 4 & $\begin{array}{l}\text { SMK } \\
\text { PGRI 4 } \\
\text { Denpasar }\end{array}$ & 4 \\
\hline $\begin{array}{l}\text { SMAN 1 } \\
\text { Denpasar }\end{array}$ & 12 & $\begin{array}{l}\text { SMKN 1 } \\
\text { Denpasar }\end{array}$ & 7 \\
\hline $\begin{array}{l}\text { SMAN 2 } \\
\text { Denpasar }\end{array}$ & 2 & $\begin{array}{l}\text { SMKN 2 } \\
\text { Denpasar }\end{array}$ & 2 \\
\hline $\begin{array}{l}\text { SMAN 3 } \\
\text { Denpasar }\end{array}$ & $\begin{array}{l}\text { SMKN 4 } \\
\text { Denpasar }\end{array}$ & 1 \\
\hline $\begin{array}{l}\text { SMAN 4 } \\
\text { Denpasar }\end{array}$ & $\begin{array}{l}\text { SMKN 5 } \\
\text { Denpasar }\end{array}$ & 6 \\
\hline
\end{tabular}

\section{c. Analisis Faktor}

Analisis faktor digunakan untuk mengetahui faktor-faktor yang memengaruhi persepsi akademis terhadap pemakaian busana adat Bali ke sekolah.

\section{Uji Kelayakan Data}

Pada dasarnya uji kelayakan data pada analisis faktor dapat dilihat dari matrik korelasi antar variabel penelitian. Analisis faktor layak dan tepat digunakan apabila variabel-variabel yang digunakan harus saling berkorelasi. Proses analisis faktor selanjutnya yaitu melihat nilai KMO dan Bartlett's Test. Untuk uji Bartlett, apabila nilai signifikansi kurang dari taraf nyata $(\alpha)$, maka analisis faktor dapat digunakan. Hasil dari uji KMO dan Bartlett's Test terangkum pada Tabel 2 
Tabel 2. Hasil uji KMO dan Bartlett's Test Data Persepsi Siswa

\begin{tabular}{|l|l|r|}
\hline \multicolumn{3}{|c|}{ KMO and Bartlett's Test } \\
\hline \multicolumn{2}{|l|}{$\begin{array}{l}\text { Kaiser-Meyer-Olkin Measure of Sampling } \\
\text { Adequacy. }\end{array}$} & .683 \\
\hline $\begin{array}{l}\text { Bartlett's Test of } \\
\text { Sphericity }\end{array}$ & Approx. Chi-Square & 712.808 \\
\cline { 2 - 3 } & df & 136 \\
\cline { 2 - 3 } & Sig. & .000 \\
\hline
\end{tabular}

Hasil uji KMO dan Bartlett's Test diperoleh nilai KMO sebesar 0,683 yang menunjukkan bahwa data yang diperoleh pada penelitian ini cukup layak untuk ditindaklanjuti dengan analisis faktor. Hasil KMO ini diperkuat dengan uji Bartlett's yang memperoleh nilai signifikansi sebesar 0,000 yang kurang dari 0,05, sehingga analisis faktor bisa digunakan pada data penelitian ini.

\section{Menentukan Jumlah Faktor}

Secara umum ekstraksi jumlah faktor dapat dilihat dari nilai akar ciri yang lebih besar dari satu $(\lambda>1)$, sehingga faktor yang memiliki nilai akar ciri lebih besar dari satu dianggap signifikan. Tabel 3 menunjukkan bahwa ada 5 komponen yang memiliki nilai akar ciri lebih besar satu, dengan total varian atau keragaman yang dapat dijelaskan 58,742 persen. Artinya ke lima komponen tersebut mampu menjelaskan persepsi sisw a terhadap penggunaan busanaadat di lingkungan sekolah sebesar 58,742 persen, dan sisanya 41,258 persen dijelaskan oleh faktor lain.

Tabel 3. Keragaman Total yang Dijelaskan Oleh Faktor

\begin{tabular}{|l|r|r|r|}
\hline \multirow{2}{*}{ Component } & \multicolumn{3}{|c|}{ Initial Eigenvalues } \\
\cline { 2 - 4 } & & \multicolumn{1}{|c|}{$\begin{array}{c}\text { To of } \\
\text { Variance }\end{array}$} & Cumulative \% \\
\hline $\mathbf{1}$ & $\mathbf{3 . 3 3 9}$ & $\mathbf{1 9 . 6 4 0}$ & $\mathbf{1 9 . 6 4 0}$ \\
$\mathbf{2}$ & $\mathbf{2 . 3 3 2}$ & $\mathbf{1 3 . 7 1 8}$ & $\mathbf{3 3 . 3 5 8}$ \\
$\mathbf{3}$ & $\mathbf{1 . 8 1 5}$ & $\mathbf{1 0 . 6 7 9}$ & $\mathbf{4 4 . 0 3 7}$ \\
$\mathbf{4}$ & $\mathbf{1 . 3 5 8}$ & $\mathbf{7 . 9 8 5}$ & $\mathbf{5 2 . 0 2 2}$ \\
$\mathbf{5}$ & $\mathbf{1 . 1 4 2}$ & $\mathbf{6 . 7 2 0}$ & $\mathbf{5 8 . 7 4 2}$ \\
6 & .953 & 5.608 & 64.350 \\
7 & .887 & 5.216 & 69.565 \\
8 & .773 & 4.547 & 74.112 \\
9 & .728 & 4.282 & 78.394 \\
10 & .653 & 3.842 & 82.236 \\
11 & .557 & 3.275 & 85.511 \\
12 & .516 & 3.033 & 88.544 \\
13 & .478 & 2.810 & 91.355 \\
14 & .443 & 2.606 & 93.961 \\
15 & .371 & 2.181 & 96.142 \\
16 & .349 & 2.051 & 98.193 \\
17 & .307 & 1.807 & 100.000 \\
\hline
\end{tabular}

Extraction Method: Principal Component Analysis.
Nilai 58,742 persen ini masih kurang memuaskan untuk menjelaskan faktor-faktor yang memengaruhi persepsi akademisi terhadap penggunaan busana adat di lingkungan sekolah. Hal ini disebabkan karena penelitian ini adalah penelitian bersifat eksplorasi, maksudnya penelitian sejenis belum ada yang meneliti, sehingga variabel-variabel yang digunakan belum teruji secara luas. Komponen pertama persentase keragamannya paling besar yaitu $19,64 \%$, ini mengindikasikan bahwa komponen tersebut mampu menjelaskan persepsi siswa terhadap penggunaan busana adat di lingkungan sekolah sebesar $19,64 \%$. Selanjutnya komponen kedua persentase keragamannya sebesar $13.718 \%$, komponen ketiga sebesar 10,679\%, komponen keempat sebesar 7,985\%, dan komponen kelima sebesar 6,72\%. Kelima komponen ini yang akan menjadi faktor-faktor yang memengaruhi persepsi siswa. Dilihat dari dimensi awal yang diduga memengaruhi persepsi siswa ada empat dimensi yaitu pengetahuan tentang aturan berbusana, pengetahuan busana adat, etika berbusana adat, dan kenyamanan berbusana adat, dan analisis faktor menghasilkan lima faktor yang baru.

\section{d. Rotasi Faktor}

Faktor-faktor yang diperoleh melalui analisis komponen utama (proses ekstraksi faktor) pada umumnya masih sulit untuk diinterpretasikan secara langsung, sehingga biasanya dilakukan suatu rotasi faktor sampai struktur yang lebih sederhana diperoleh. Rotasi yang digunakan dalam penelitian ini adalah rotasi varimax with Kaiser Normalization. Rotasi ini digunakan karena diasumsikan bahwa, faktor-faktor yang memengaruhi persepsi siswa tidak saling berkorelasi. Setelah mendapatkan hasil dari rotasi faktor, akan diketahui variabel-variabel mana saja yang masuk ke dalam satu faktor. Hasil output dari rotasi faktor dapat dilihat pada Tabel 4.

Dasar pertimbangan yang digunakan untuk memutuskan apakah suatu variabel dikategorikan ada faktor 1 , faktor 2 , atau faktor lainnya adalah dengan cara melihat nilai faktor loadingnya. Dalam penelitian ini keanggotaan dari masing-masing faktor adalah sebagai berikut: Item pertanyaan X4.1, X4.2, X4.3, X4.4 dan X4.5 mengelompok pada faktor 1, menunjukkan item-item pertanyaan tersebut merupakan komponen dari faktor 1. Selanjutnya faktor 1 ini dinamai faktor "Kenyamanan dalam berbusana adat". 
Tabel 4. Hasil Rotasi Varimax

Rotated Component Matrix ${ }^{a}$

\begin{tabular}{|l|r|r|r|r|r|}
\hline & \multicolumn{5}{|c|}{ Component } \\
\cline { 2 - 6 } & \multicolumn{1}{|c|}{1} & \multicolumn{1}{|c|}{2} & \multicolumn{1}{c|}{3} & \multicolumn{1}{c|}{5} \\
\hline $\mathrm{X} 1.1$ & -.224 & .702 & -.040 & .078 & .273 \\
$\mathrm{X} 1.2$ & -.078 & .641 & .096 & .131 & .152 \\
$\mathrm{X} 1.3$ & .140 & .739 & -.002 & .335 & -.028 \\
$\mathrm{X} 1.4$ & -.027 & .425 & .245 & -.020 & .401 \\
$\mathrm{X} 1.5$ & .033 & .234 & .004 & .058 & .726 \\
$\mathrm{X} 2.1$ & -.180 & .236 & .272 & .175 & .636 \\
$\mathrm{X} 2.2$ & .143 & .163 & .694 & -.135 & .207 \\
$\mathrm{X} 2.3$ & -.104 & .260 & .721 & -.122 & -.043 \\
$\mathrm{X} 3.1$ & .136 & -.114 & .609 & .454 & .005 \\
$\mathrm{X} 3.2$ & -.096 & -.156 & .697 & .207 & .048 \\
$\mathrm{X} 3.3$ & -.036 & .193 & .125 & .764 & .035 \\
$\mathrm{X} 3.4$ & -.012 & .295 & -.072 & .762 & .153 \\
$\mathrm{X} 4.1$ & .656 & .108 & .110 & -.325 & -.152 \\
$\mathrm{X} 4.2$ & .773 & .012 & .018 & .032 & -.214 \\
$\mathrm{X} 4.3$ & .652 & -.037 & -.161 & -.047 & .275 \\
$\mathrm{X} 4.4$ & .523 & -.291 & -.160 & .064 & .501 \\
$\mathrm{X} 4.5$ & .685 & -.161 & .076 & .152 & .008 \\
\hline
\end{tabular}

Extraction Method: Principal Component Analysis. Rotation Method: Varimax with Kaiser Normalization. a. Rotation converged in 8 iterations.

Variabel-variabel X1.1, X1.2, X1.3, dan X1.4 mengelompok pada faktor 2 dan merupakan komponen dari faktor 2, faktor 2 ini dinamai faktor "Pengetahuan tentang aturan berbusana adat". Komponen dari faktor 3 adalah variabel X2.2, X2.3, X3.1, dan X3.2, yang dinamai dengan faktor "Pengetahuan tentang busana adat". Item pertanyaan yang merupakan komponen dari faktor 4 adalah X3.3 dan X3.4, faktor 4 ini dinamai dengan "Etika berbusana adat Bali. Terakhir, item pertanyaan X1.5 dan X2.1 merupakan komponen dari faktor 5, yang selanjutnya dinamai dengan "wisatawan dan busana adat Bali". Adapun pengelompokan variabel menjadi komponen dari faktornya terangkum pada Tabel 5 berikut.

Tabel 5. Pengelompokan Variabel dari 5 Faktor

\begin{tabular}{|c|c|c|}
\hline Faktor & $\begin{array}{c}\text { Nomor item } \\
\text { pertanyaan }\end{array}$ & Keterangan \\
\hline $\begin{array}{l}\text { 1. Kenyamanan } \\
\text { dalam berbusana } \\
\text { adat Bali }\end{array}$ & $\begin{array}{l}4.1,4.2,4.3,4.4 \\
\text { dan } 4.5\end{array}$ & $\begin{array}{l}\text { 1. Merasa kepanasan ketika menggunakan busana adat Bali di } \\
\text { sekolah } \\
\text { 2. Merasa keluwesan bergerak terganggu ketika menggunakan } \\
\text { busana adat Bali di sekolah } \\
\text { 3. Meras a susah berkonsentrasi ketika menggunakan busana adat } \\
\text { Bali di sekolah } \\
\text { 4. Ketidakseragaman busana adat Bali yang digunakan di sekolah } \\
\text { menyebabkan kurang rasa percaya dirianda } \\
\text { 5.Penggunaan busana adat Bali menyusahkan anda diperjalanan } \\
\text { menuju ke Sekolah }\end{array}$ \\
\hline $\begin{array}{l}\text { 2. Pengetahuan } \\
\text { tentang aturan } \\
\text { berbusana adat }\end{array}$ & $\begin{array}{l}1.1,1.2,1.3, \text { dan } \\
1.4\end{array}$ & $\begin{array}{l}\text { 1. Pengetahuan tentang peraturan penggunaan busana adat Balike } \\
\text { sekolah } \\
\text { 2. Sering tidaknya mendengar atau membaca tentang peraturan } \\
\text { penggunaan busanaadat Bali ke sekolah } \\
\text { 3. Ada tidaknya sosialis asi aturan peng gunaan busana adat. } \\
\text { 4. Penggunaan busana adat dapat meningkatkan wawasan budaya } \\
\text { daerah }\end{array}$ \\
\hline $\begin{array}{l}\text { 3. Pengetahuan } \\
\text { busana adat }\end{array}$ & $\begin{array}{l}2.2,2.3,3.1 \text { dan } \\
3.2\end{array}$ & $\begin{array}{l}\text { 1. Pengetahuan tentang fungsipeng gunaan busana adat dalam } \\
\text { keseharian } \\
\text { 2. Pengetahuan pengelompokan penggunaan busana adat Bali } \\
\text { 3. Pengertian etika berbusana adat Bali } \\
\text { 4. Keserasian dalamberbusana adat Bali }\end{array}$ \\
\hline $\begin{array}{l}\text { 4. Etika berbusana } \\
\text { adat Bali }\end{array}$ & 3.3 dan 3.4 & $\begin{array}{l}\text { 1. Menerapkan etika berbusana adat Bali di kehidupan sehari-hari. } \\
\text { 2. Menerapkan etika berbusana adat Bali di lingkungan sekolah }\end{array}$ \\
\hline $\begin{array}{l}\text { 5. Wis atawan dan } \\
\text { busana adat Bali }\end{array}$ & 1.5 dan 2.1 & $\begin{array}{l}\text { 1.Penggunaan busana adat dapat menarik perhatian wis atawan } \\
\text { akan budaya Bali itu sendiri } \\
\text { 2. Pengertian busana adat }\end{array}$ \\
\hline
\end{tabular}




\section{SIMPULAN DANSARAN}

\section{Simpulan}

Adapun simpulan penelitian ini adalah sebagai berikut:

1. Faktor yang memengaruhi persepsi siswa terhadap penggunaan busana adat di lingkungan sekolah adalah kenyamanan dalam berbusana adat, pengetahuan tentang aturan berbusana adat, pengetahuan tentang busana adat, etika berbusana adat Bali dan wisatawan dan busana adat Bali. Kelima faktor ini dapat menjelaskan keragaman persepsi siswa sebesar 58,742 persen.

2. Faktor dominan yang memengaruhi persepsi sisw a terhadap penggunaan busana adat di lingkungan sekolah adalah kenyamanan dalam berbusana adat.

3. Ada lima variabel yang menjelaskan tentang kenyamanan dalam berbusana adat, yaitu: 1 . merasa kepanasan ketika menggunakan busana adat Bali di sekolah; 2. merasa keluwesan bergerak terganggu ketika menggunakan busana adat Bali di sekolah; 3. merasa susah berkonsentrasi ketika menggunakan busana adat Bali di sekolah; 4. Ketidakseragaman busana adat Bali yang digunakan di sekolah menyebabkan kurang rasa percaya diri anda; 5. Penggunaan busana adat Bali menyusahkan anda diperjalanan menuju ke Sekolah.

\section{Saran}

Adapun saran yang dapat diberikan berdasar penelitian yang telah dilaksanakan adalah sebagai berikut:

1. Hasil penelitian yang menunjukkan bahwa kenyamanan dalam berbusana adat merupakan factor dominan yang memengaruhi persepsi siswa terhadap penggunaan busana adat di lingkungan sekolah, merupakan peringatan buat sekolah dan pemerintah daerah dalam menjalankan program berbusana adat ini untuk lingkungan akademik.

2. Total keragaman yang hanya 58,742 persen mengindikasikan masih sangat diperlukannya kajian mendalam terutama terkait dengan penyusunan item pertanyaan yang lebih dapat menjelaskan tentang persepsi berbusana.

\section{DAFTAR PUSTAKA}

Adam, H. \& Galinsky, A. D. (2012). Enclothed Cognition. Journal of Experimental Social Psychology, 48, 918-925.

Guerrero, L. and A. Posthuma, R. (2014), "Perceptions and behaviors of Hispanic w orkers: a review", Journal of Managerial Psychology, Vol. 29 No. 6, pp. 616643. https://doi.org/10.1108/JMP-07-2012$\underline{0231}$

Rakhmat (2005). Rakhmat, Jalaludin. 2005. Psikologi Komunikasi. Bandung: PT. Remaja Rosdakarya.

Sugiyono. 2010. Metode Penelitian Pendidikan Pendekatan Kuantitatif, kualitatif, dan $R \& D$. Bandung: Alfabeta

Sugiyono, 2001. Metode Penelitian, Bandung: CV Alfa Beta.

Walpole, Ronald E. (2007) Pengantar Statistika Edisi Ke - 3 PT. Gramedia Pustaka Utama, Jakarta 